\title{
Applications of bioimpedance measurement
}

\section{techniques in tissue engineering}

\author{
M. Amini ${ }^{1,4}$, J. Hisdal ${ }^{2}$, H. Kalvøy ${ }^{3}$ \\ 1. Department of Physics, University of Oslo, Oslo, Norway \\ 2. Vascular Investigations and Circulation lab, Aker Hospital, Oslo University Hospital, Oslo, Norway \\ 3. Department of Clinical and Biomedical Engineering, Rikshospitalet, Oslo University Hospital, Oslo, Norway \\ 4. Email any correspondence to: maryamam@fys.uio.no
}

\begin{abstract}
Rapid development in the field of tissue engineering necessitates implementation of monitoring methods for evaluation of the viability and characteristics of the cell cultures in a real-time, non-invasive and non-destructive manner. Current monitoring techniques are mainly histological and require labeling and involve destructive tests to characterize cell cultures. Bioimpedance measurement technique which benefits from measurement of electrical properties of the biological tissues, offers a non-invasive, label-free and real-time solution for monitoring tissue engineered constructs. This review outlines the fundamentals of bioimpedance, as well as electrical properties of the biological tissues, different types of cell culture constructs and possible electrode configuration set ups for performing bioimpedance measurements on these cell cultures. In addition, various bioimpedance measurement techniques and their applications in the field of tissue engineering are discussed.
\end{abstract}

Keywords: Tissue Engineering, Bioimpedance Measurement, Non-invasive monitoring

\section{Problem Definition}

Tissue engineering is the science of generating tissues for replacing the malfunctioning tissues or organs in the body. Advances in biotechnology and material science has led to rapid developments in the field of tissue engineering $(1,2)$. Polymers, hydrogels and decellularised animal tissues are different types of biomaterials that are used to generate tissue engineered constructs in combinations with cells (3, 4).

Due to the potential of generating differentiated cells, the tissue engineered constructs are commonly, first cultured in vitro before their in vivo transplantation (3).

In order to evaluate tissue-engineered constructs, methods should be employed which would be able to provide information regarding the morphological and functional behavior of the cell cultures in a real-time and non-invasive manner (5). Due to the high costs and small number of donors, the monitoring methods should be ideally non-destructive to the cell cultures. Currently used technique for the purpose of investigating tissue engineered cultures provide helpful information about the characteristics of the tissue engineered constructs. However, these methods such as histology staining, are destructive and time-consuming and require fixing and cutting the tissue cultures (6).

Therefore, there is a need for real-time and noninvasive monitoring techniques to evaluate the quality of the tissue engineered constructs before implanting them in the body, without the need to use fluorescents or radioactive labels or destructive methods. This in addition, would reduce the number of animals required for this purpose $(5,6)$.

\section{Bioimpedance Measurements} Basics of bioimpedance

Bioimpedance is defined as the ability of the biological tissue to impede (oppose) electrical current and is considered a passive electrical property. Bioimpedance can

(C) 2018 M. Amini, J. Hisdal, H. Kalvøy. This is an open access article licensed under the Creative Commons Attribution-NonCommercial-NoDerivs License (http://creativecommons.org/licenses/by-nc-nd/3.0/). 
be measured by detecting the response to electric excitation (either current or potential) which is applied to a biological tissue. In bioimpedance measurements, applying the excitation signal and picking up the response is performed by the same or other electrodes which convert the electronic charge to ionic charge and vice versa (7).

Electrical Impedance ( $\mathrm{Z}$ ) which is the ratio of the voltage (V) and current (I), applies to alternating current (AC). Resistive (R), capacitive (C) and inductive (L) components of the tissue, all contribute to the measured impedance;

$$
\mathrm{Z}=\mathrm{V} / \mathrm{I}
$$

As $Z$ is a complex function, it can be expressed by the modulus $|Z|$ and the phase shift $\Phi$ or by the real part $R$ which represents resistance, and the imaginary part $X$ representing capacitance. Important to note that the imaginary part would be zero when direct current is applied.

Admittance $(Y)$ is the inverse of impedance which means admitting current flow. Impedance and admittance are basically both AC parameters and frequency dependent (7).

\section{Electrical Properties of biological tissues}

It was shown in early 1900s that cells viability could be evaluated by measuring the electrical properties of cells (8). Electrical properties of the biological tissues depend on physiological, morphological, and pathological conditions of the tissue, as well as the frequency of the electrical signal applied $(9,10)$.

Electrical properties of biological tissues based on the source of the electricity, can be either active (endogenous) or passive (exogenous). Active properties (bioelectricity) arise from the ionic activities inside cells (typical for nerve cells), such as electrocardiograph (ECG) signals from the heart and electroencephalograph signals (EEG) form the brain. Passive properties occur due to simulation by an external electrical excitation source $(8,11)$. In this article, the passive properties of the biological tissues would be discussed.

Biological tissues are comprised of cells with membranes, surrounded by extracellular fluids (12). This way the extra and intracellular spaces are separated by cell membranes, which creates two electrically conducting compartments: extra and intracellular media. The intracellular and extracellular fluids provide resistive paths. The lipid bilayer cell membrane, on the other hand, is very thin (around $7 \mathrm{~nm}$ ) and semi-permeable, which due to its insulating nature, gives the membrane a high capacitance and produces capacitive reactance $(7,13,14)$.

Biological tissues can also demonstrate inductive properties, but when compared to their resistance and reactance, inductance is very low at frequencies below $10 \mathrm{MHz}$, therefore it can often be neglected (15). Thus, the complex electrical impedance produced by biological tissues which can also be called bioimpedance, is the result of contribution of both capacitance and conductance of the tissues which are both frequency-dependent $(9,16-20)$.

Permittivity $(\varepsilon)$ is also one of the electrical properties of the biological tissues. Schwan was the first to study the dielectric properties of biological tissues in 1957 and realized that both permittivity $(\varepsilon)$ and conductivity $(\sigma)$ are frequency dependent factors (21). Permittivity is the ability to permit storage of electric energy (7) and is a measure of the system response when an electric field is applied (16, 22).

Under linear conditions for a biological tissue, cell admittance $(\mathbf{Y})$, cell impedance $(\mathbf{Z}=\mathbf{1} / \mathbf{Y})$ and permittivity $(\varepsilon)$ all provide the same information (7). Permittivity is mostly expressed as relative permittivity and decreases with the increase in frequency. This is because of the inability of the tissue to react to the quick changes in the applied electrical field $(9,23,24)$.

While analyzing the properties of biological tissues over a large frequency range, Schwan realized that these dielectric properties are characterized by three dispersions including: $\alpha$-dispersion, $\beta$-dispersion, and $\gamma$-dispersion, which occur respectively at low frequency, radiofrequency, and microwave frequency $(21,25)$;

1. $\alpha$-dispersion $(10 \mathrm{~Hz}$ to a few $\mathrm{kHz})$ : associated with tissue interfaces, such as membranes (21).

2. $\beta$-dispersion ( $1 \mathrm{kHz}$ to several $\mathrm{MHz}$ ): caused by the polarization of cellular membranes and protein and other organic macromolecules

3. $\gamma$-dispersion $(\geq 10 \mathrm{GHz}$ ): associated with the polarization of water molecules

At low frequencies, cell membranes act as insulating barriers demonstrating resistive pathways, therefore little or no current would be able to pass the cell membranes, while at higher frequencies, the capacitive pathways of the membrane would be demonstrated and the current would be able to pass through the cells due to the high capacitance of the cell membrane (Figure 1) (26). At very high frequencies, resistive or capacitive pathways do not have much contribution as the current does not have time to flow and it would only bounce back and forth between membrane surface of the cells $(18,27)$.
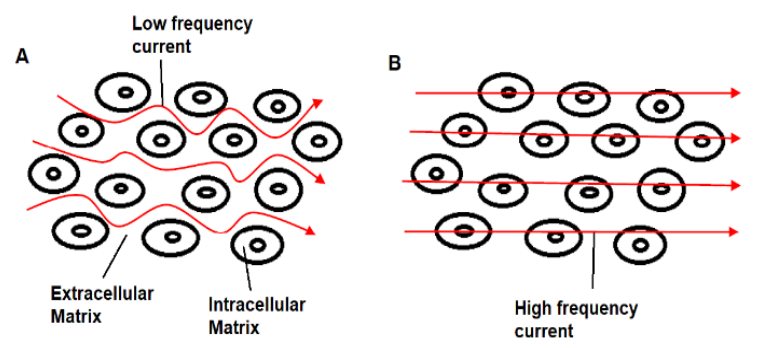

Figure 1. Flow of electrical current through biological tissue: A) At lower frequencies, current flows between the cells and through the extracellular fluid, B) At high frequencies, current penetrates the cell membranes and flows through intracellular and extracellular fluid. 
In order to study the behavior and activity of cells in a tissue engineered cell construct, the evident method would be applying an AC electric field to the cell culture and measuring the passive electrical response of the cells, i.e. electrical properties of the cell construct $(14,28,29)$. This can be considered as a practical method for monitoring cell growth and differentiation in a non-invasive and label-free manner for tissue engineering applications $(30,31)$.

Common electrode configurations for bioimpedance measurements

In bioimpedance measurements, when an alternating current is applied, electrode demonstrates an impedance at its interface with the tissue/solution which is highly dependent on frequency (Electrode polarization impedance). Changes in the type of material (tissue or solution) which is in contact with the electrode, influence the magnitude and phase of the electrode impedance. Therefore the final measured impedance by the system, is the sum of electrode polarization impedance and the impedance of the tissue or solution (7). For a given electrode material and type, impedance would be determined by the magnitude of the excitation signal as well as the electrode dimensions and geometrical structure (32). In order to perform bioimpedance measurements, a minimum number of two electrodes are needed which would create a closed circuit for the passage of the electrical current (7).

To monitor the characteristics of a tissue engineered construct, different electrode configurations can be used. Impedance at the interface between the electrode and electrolyte or the cell culture (electrode polarization impedance) is more reflected by two and three electrode configurations and influences the measurements (33). While combining the two and four electrode configurations, different volume layers of the same tissue engineered cell culture with less contribution from the electrode polarization impedance can be studied $(34,35)$. This combined electrode configuration can be used to provide structural information during the growth and differentiation process of the stem cells in a nondestructive way $(36,37)$. Moreover, by benefitting from the combinations of two, three and four electrode configurations, more electrode pairs with various spatial distributions can be applied to study the spatial distribution of cells in a 3D cell construct. It should be noted that factors such as movement and wrong positioning of electrodes, can be the source of error in bioimpedance measurements (32).

\section{Two electrode configuration}

The most evident set up for impedance measurements is the two electrode configuration (Figure 2), where the same electrode pair is used for both current-carrying (CC) and voltage pickup (PU).
The impedance which is measured this way consists of the polarization impedance at the surface of the electrodes, as well as information regarding the volume of the tissue around the electrodes (7). This electrode configuration, can also be used for unipolar measurements where one very small and one large electrode are used (38).

Two electrode configuration is the simplest set up that can be used for impedance measurements in perfusion based systems (33-35). It is also typically used for impedance measurements in monolayer cell cultures where the electrodes are inserted at the bottom of the cell culture vessel (39). Electric Cell substrate Impedance Spectroscopy (ECIS), is the example of one the impedance measurement methods on cell monolayers which applies two electrode configuration set up. In this method cells would be grown on the surface of the sensing electrode and changes in the impedance is measured between the sensing and the counter electrode. The measured impedance would be very dependent on the coverage of the electrode surface by cells. The results achieved this way, although interesting, but do not provide accurate measurement of the tissue volume grown on the surface of the electrode (40). One alternative can be using several electrode pairs and changing the distance between the electrodes to be able to achieve different penetration depth in the layers of cell culture (41).

Main limitation of the two electrode configuration systems is presence of electrode polarization impedance in the output signal which should be considered and extracted while analyzing the measured signal $(34,42)$.

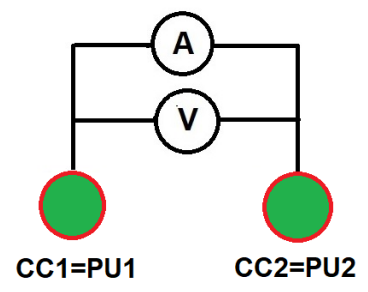

Figure 2. Schematic of a two electrode configuration set up, where both electrodes are used for current carrying (CC) and voltage pick up (PU).

\section{Three electrode configuration}

In three electrode configuration (Figure 3), an external voltage is applied between the reference (RE) and the working electrode (WE), and electric current is passed from the counter electrode (CE) to the working electrode (WE). The potential of the reference electrode is considered constant as no current flows through this electrode. Therefore changes in the potential of the working electrode is the same as the change in the applied voltage (7). Canali et al., applied a combination of two and three plate electrode configurations to study the spatial distribution of cells in large gelatin scaffolds (43). 


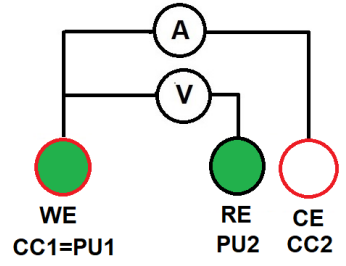

Figure 3. Schematic of a three electrode configuration set up, where an external voltage is applied between the reference (RE) and the working electrode (WE), and electric current is passed from the counter electrode (CE) to the working electrode (WE).

\section{Four electrode configuration}

Four electrode configuration was introduced in late 1800's to measure materials resistivity (44). In this set up, a pair of electrodes are used for applying the current into the tissue sample (CC) and the other electrode pair is used for detecting the changes in the voltage (PU) as the result of changes in the conductivity of the tissue (Figure 4) $(34,35)$. In four electrode configuration set up, increasing the distance between the CC and PU electrode pairs would lead to decrease in the magnitude of the measured impedance $(7,45)$.

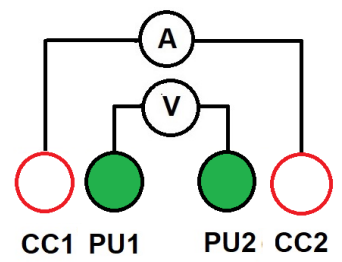

Figure 4. Schematic of a four electrode configuration set up. CC1 and $\mathrm{CC} 2$ are the current carrying electrodes while PU1 and PU2 are the voltage pick up electrodes.

One of the advantages of four electrode configurations in comparison to two electrode configuration is that as the $\mathrm{PU}$ electrodes are non-current carrying, the polarization impedance would be eliminated and therefore the effect of the contact impedance at the electrode and tissue or electrolyte interface would be minimized. This way only the electrical properties of the biological tissue would be detected (46).

Moreover, measurements with four electrode configuration can have a higher sensitivity and accuracy in measuring the density of the biological tissues and providing morphological information. While with two electrode configuration, the measurements can often be dominated by the electrode polarization impedance which can make it difficult to extract the contribution from the tissue with sufficient sensitivity or accuracy $(36,37)$. In general, the influence of electrode polarization impedance is dependent on electrode material, size, measurement frequency, sample impedance, etc. Hence, it is important to be aware of this effect and if necessary, employ different techniques to reduce it. Using a four electrode set-up is a well-known method for reducing the influence of electrode polarization impedance, but other methods have also been suggested (47).

\section{Different types of tissue engineered constructs}

Two dimensional (2D) or monolayer cell cultures are typically used for the purpose of research on biological tissues at the cellular level $(48,49)$. Due to cellular heterogeneity, it is important to study single cells as cells are not necessarily a representative of the features of the whole tissue they are extracted from. However, a 2D cell culture, provides an artificial environment which lacks characteristics such as concentration gradient which can be provided by a three dimensional (3D) in vitro cell culture system. Therefore, there is still a gap between the two and three dimensional cell culture systems and a proper functioning biological tissue. As a solution, chip based 3D culture systems are developed to overcome the limitations of the $2 \mathrm{D}$ and $3 \mathrm{D}$ cell culture models (50-52).

\section{Two-Dimensional (2D) cell culture}

In 2D cell culture systems, cells are seeded into a cell culture vessel (Figure 5), which contains a volume of cell culture medium with a height ranging from $\mathrm{mm}$ to $\mathrm{cm}$ above the cells. This cell culture medium contains the nutrients and gasses needed for cells growth and takes up waste products (52). 2D cell cultures provide a simple system for observation and evaluation of cellular behavior and has been employed in different studies such as cancer drug screening $(48,49)$.

The morphological evaluation of the cell monolayer or $2 \mathrm{D}$ cell cultures, is usually performed using an optical microscope. Optical methods based on fluorescent staining are commonly used for studying cell activities. However, fluorescent staining normally kills the cells. On the other hand, the penetration depth of the commonly employed techniques for 2D cell cultures such as confocal and fluorescence microscopies, are limited ( $<50$ micrometers) (53). Therefore, as an alternative approach for real-time and non-invasive and label-free measurements, bioimpedance measurement techniques can be applied (54).

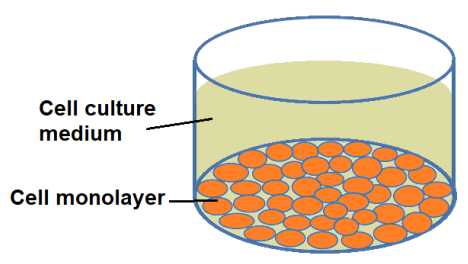

Figure 5. Schematic representation of the 2D cell culture where cells are seeded as individual cell into a cell culture dish.

\section{Three-Dimensional (3D) cell culture}

Cells in vivo, are in interaction with extracellular matrix and neighboring cells which provides them with a threedimensional environment. Therefore when removed from 
this native three- dimensional environment (3D) and limited to a monolayer (2D), cells would show unnatural behavior $(48,49)$. Due to the resemblance to in vivo situations and the ability to provide a physiologically relevant environment, three-dimensional (3D) cell cultures have been developed $(48,55)$. To mimic the in vivo environment, cells are encapsulated within 3D scaffolds (56), where the properties of the scaffolds such as stiffness, composition and porosity have an important influence on cell physiology (57-59).

There are different 3D cell cultures based on the type of Extra Cellular Matrix (ECM), including:

1. Artificial ECM (synthetic polymers, alginate ...)

2. Natural ECM (collagen, hyaluronic acid...)

3. None ECM or scaffold-free (3D spheroids or microtissues) (Figure 6) $(60,61)$

Encapsulation of the cells in the scaffold in a 3D cell culture system, makes direct evaluation of cellular growth and behavior difficult and time consuming (62). Techniques such as histopathology, scanning electron microscopy and transmission electron microscopy, can be employed for studying the cells but are destructive in nature as the cells need to be frozen and fixed to be evaluated by these methods (63). Thus, bioimpedance measurement techniques can provide non-invasive monitoring of 3D tissue engineered constructs by applying different electrode geometries and configurations.

Long-term and real-time monitoring of cell growth and differentiation leading to tissue formation in 3D scaffolds is of high importance in tissue engineering applications, as the cell cultivation process is performed over time (53). For impedance measurements in 3D culture systems, cells are not seeded as a monolayer on the surface of the electrode but are encapsulated in a 3D scaffold which is in contact with a conductive medium (52). Thus, the electrodes can be placed for example outside the extracellular matrix and in the middle to provide impedance measurements.

Therefore, the ionic variations of the medium over time would lead to changes in conductivity which would affect the measured impedance (43).

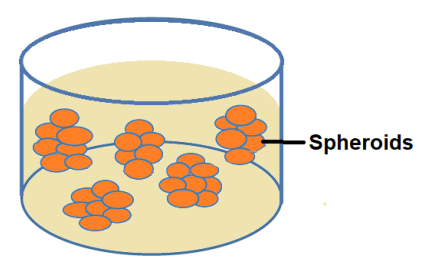

Figure 6. Schematic representation of a scaffold free 3D cell culture in the form of spheroids.

\section{Microfluidic 3D cell culture or Lab-on-chip}

The development of microfluidic 3D cell culture systems was originally based on the concept of scaling down cell culture systems $(64,65)$. Microfluidic 3D cell culture systems or devices, also called organ-on-chip, bio-chip, body-on-chip or micro-total-analysis-system $(66,67)$ are devices containing microfluidic channels and chambers for culturing living cells. Their purpose is to provide microenvironments which mimic in vivo conditions and provide measurement of cell performance by benefiting microfabricated chips (Figure 7) $(64,68,69)$. In LOC systems, components of a 3D culture system such as natural extra cellular matrix as the substrate and 3D gels for filling the microfluidic chambers are combined with the microfluidic design (70). These systems are considered a miniaturized and automatized version of the conventional laboratory as they incorporate most of the necessary and functional components of a laboratory in to a small chip (71).

The advantages of LOC systems such as higher reliability and increased sensitivity and specificity, and lower costs due to less material consumption, are mostly due to their miniaturized sized and automation. In addition, microfluidic systems also take into consideration the fluid transport that is usually neglected in other cell culture systems (72). In addition, the microfluidic systems which is an in vitro cell culture systems of high complexity, provides the possibility to assess the permeability of the cellular barriers $(73,74)$.

Evaluation of cell adhesion, spreading, growth, motility and death for any adherent cell type is possible in LOC systems by monitoring the impedance changes at the contact between the cells and electrodes (75). Impedance measurements can also be used in studying cytotoxicity which provides an alternative method for slow and invasive traditional cytotoxicity assays (14).

Cells that are attached to the substrate of cell culture systems are considered the sensing elements and therefore, monitoring their viability and functionality is of high importance. Changes in cell differentiation, motility, morphology, adhesion and etc., all characterize cell viability. On the other hand, drastic changes in behavior of the cells, such as morphology, integrity of extracellular membrane, as well as changes in intracellular structure would characterize cell death (76). These changes all have an important influence on the measured impedance which can be detected quickly and inexpensively by impedance electrodes (75).

A fully integrated physical, biochemical and optical sensing platform interfaced with a multi-organ-on-a-chip system was developed by Zhang et al. This system provided automated, and on-line sensing of biophysical and biochemical parameters of a microfluidic environment (51). Moreover, there are reports of microfluidic devices which provide automated and cost effective cell culture systems by using an array of microchambers inside which cells are cultured and continuous perfusion of medium is provided $(62,77)$. 
A

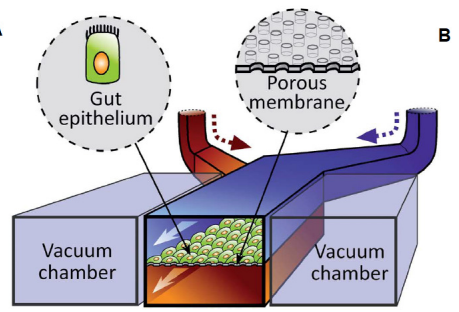

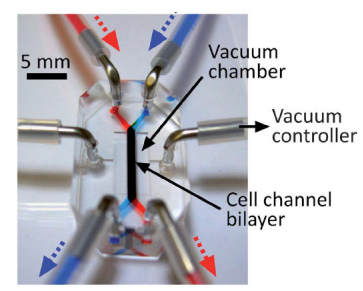

Figure 7. A) Organ on chip device showing an extra cellular matrix (ECM) coated flexible porous membrane with epithelial cells through the middle of the central microchannel and vacuum chambers on both sides; B) Picture of the organ on a chip device (directions indicated by arrows visualize perfusion of the red and blue dyes). Copied with permission (78).

Common bioimpedance measurement techniques applied in tissue engineering

Real-time and non-invasive monitoring and characterization of tissue engineered constructs during their development process is essential. The complex structure of 3D cell cultures makes this evaluation process more difficult.

Many studies have been performed in order to find the reliable non-invasive technique to study the characteristics of different tissue engineered cell cultures and for different research objectives such as evaluating stem cell differentiation protocols $(32,62,79,80)$. Optical-based methods based on fluorescence, density, light absorbance and scattering can be considered as reliable methods for cell suspensions, but are difficult to be incorporated for evaluations of cells in microporous scaffolds (6). Scanning electron microscopy is destructive to the tissue engineered construct as it needs slide cuts of the cell culture for its evaluation. Nuclear and magnetic resonance imaging although offer a reliable monitoring method, but can damage the cell culture due to their ionizing nature and are in addition costly and of low portability (5). The biomass monitor which is based on capacitance measurements, is a good method for monitoring immobilized cells in bioreactors, although measurements within microporous scaffolds are not possible with this method due to its design (81).

As a result, indirect methods for evaluation of cell growth, which measure the metabolic/protein content such as ATP, DNA, or the rate of oxygen-uptake are being employed. MTT assay that culminates in cell death, and Alamar blue dye are examples of indirect measurements used for the evaluation of cytotoxicity (82), but these methods should be performed in several stages and are not proper for on-line monitoring of cell cultures.

On the other hand, electrical impedance measurements provide a simple and reliable method for characterization and evaluation of cell cultures such as their size and shape, the state of cell membranes and the status of intra and extra cellular media $(18,83)$, as due to the nature of the impedance measurement technique, small changes in the electrical properties of cells can be detected (26).
As an example, impedance measurements have been used for continuous monitoring of tissue spheroids $(62,84$, $85)$, as well as estimating the cell size $(84,85)$, proliferation (62), evaluation of cell concentration (86) and cell viability $(87,88)$. In addition, this method has been used for monitoring cells behavior by application of bulk (89) or thin film electrodes (90), on cells attached to a substrate (91), on cells in suspension (92) or on trapped single cell (93).

Microsystems can provide an environment for cell cultures where noninvasive monitoring of cell behavior through electrical methods is possible $(71,94)$. These microsystems can be used for a variety of applications such as detecting changes in electrical properties of cells $(75$, $95)$, counting and discrimination of cell population $(96,97)$, monitoring cellular functions like cell growth and cell death (98) and cell cycle (99). Therefore, it can be concluded that impedance measurement is a non-destructive and reliable technique for monitoring the behavior of cell cultures with a high temporal resolution.

\section{EIS (Electrical/ Electrochemical Impedance Spectroscopy)}

\section{Description}

Impedance Spectroscopy (EIS) has been applied to biological tissues as early as 1925 by Fricke \& Morse (100), and is performed by recording the electric impedance of a tissue over a frequency range, where frequency-dependent electrical properties of biological tissues can be detected. Since the electrical properties of biological tissues are related to their physiological and morphological properties, therefore impedance spectroscopy can be used as a method for evaluation of tissue composition (18).

Changes occurring at the interface between the electrode and electrolyte or the tissue are of electrochemical nature (101) and are the results of resistive or capacitive properties of the materials, which both contribute to the measured impedance (102-105). Studying impedance of biological tissues across a frequency range have shown that the real part of the impedance is associated with resistive pathways across the tissues and is typically large at low frequencies, such as $10 \mathrm{~Hz}$ or lower but decreases with increasing frequency; whereas, the imaginary part of the impedance is associated with capacitive pathways and decreased at high frequencies (18, 27).

\section{Application}

In recent years, EIS has been used for various applications including tissue engineering, characterization of biological cells and cell culture monitoring $(27,38,83,106-113)$.

It is shown that applying an electric field with high voltage pulses can cause breakdown in the cell membrane, which leads to changes in the integrity and resistivity of the cell membrane (110). As the characteristics of the cell membrane and intra and extracellular spaces influence the 
impedance spectrum, therefore measuring electrical impedance of a volume of a biological tissue over a frequency spectrum provides information with regards to the quantitative changes of cells such as cell population (111).

Impedance spectroscopy has been used as a method for monitoring the growth and differentiation of stem cells in different tissue engineering applications. For example, different researchers have studied the development of Human mesenchymal stem cells using impedance spectroscopy $(30,114)$. By applying EIS, a significant increase in the measured impedance magnitude of osteogenic treated human mesenchymal stem cells was detected in comparison to the control samples (30). Furthermore, an impedance spectroscopy method using oscillating circuit for the real-time monitoring of growth and differentiation of muscle stem cells has been reported (115).

Other applications of EIS include the quantification of cell size, and number and classification of cell type and shape $(116,117)$. Moreover, this method can provide information regarding cell toxicity, cell invasion or inflammation $(79,118)$. EIS can also be used for real-time monitoring of cell attachment and spreading on substrates and studying changes in endothelial monolayers (119).

Using a single-channel impedance spectroscopy, Wang et al., introduced a low cost and reliable position detection technology for cell and particles (120).

Application of EIS for real-time and in-vivo monitoring of the healing of bone critical size defects (CSD) as well as effectiveness of biomaterials and bone tissue engineering for the treatment of CSD, was reported by Kozhenvikov et al. Moreover, the possibility of evaluating quantitative changes in collagen and Hyaluronic Acid in the fracture site using EIS was demonstrated (121).

Characterizing cell suspensions in a bioreactor or in a cell monolayer is another application of EIS $(122,123)$, which aims to evaluate the effect of growth factors and culture medium on cell differentiation $(116,117)$.

Two different EIS measurement systems proper for different kinds of cell cultures were designed by MartinezTeruel et al. The first system was employing low frequency (1-200 kHz) for measuring adherent animal cell cultures, while the second one would apply higher frequency (100 $\mathrm{kHz}-20 \mathrm{MHz}$ ) for measuring bacteria and yeast cell cultures in suspension, also feasible in single use bioreactors (116).

\section{Strength and weaknesses}

EIS is a real-time and non-invasive monitoring method which is relatively low cost and can be used for the characterization of tissue engineered constructs $(18,83)$. To obtain optimal results with this method from the measurement sample, the proper frequency range and EIS technique should be implemented. The impedance measured by EIS can also be influenced by many factors such as electrode oxidation and polarization which can lead to higher error percentage (124). EIS is very sensitive to the permittivity of cell membranes and therefore can precisely asses changes in cell cultures under high voltages, by incorporating advanced mathematical modeling methods (125). Being label-free is the clear advantage of EIS over the other characterization methods which require complex processes of preparation and dying of the samples and are usually destructive. However, EIS is less specific in comparison to non-label-free techniques, as it might be difficult to isolate different tissue volumes and therefore finding the right electrode configuration which would provide more specific measurements is of importance (116).

\section{ECIS (Electric Cell-substrate Impedance Sensors) / Impedance-Based Assays}

Description

In 1984, Giæver and Keese showed that impedance spectroscopy can be applied for monitoring adhesion, spreading and proliferation of cells on a flat surface. The method was called Electric Cell-substrate Impedance Sensing, also known as ECIS. In ECIS a weak alternating current of $(1 \mu \mathrm{A})$ is applied and the resulting impedance changes between a small sensing electrode on which cells are cultured and a large counter electrode are measured. Changes in the measured impedance occur because the electrode current is constrained by the insulating membrane of the cells cultured on the electrode surface and this way the electric current is forced to flow either under or between the cells (Figure 8$)(40,126)$.

When cells attach and start proliferating on the electrode surface, due to their low conductivity at low frequencies, the measured impedance increases and this is directly proportional to the area of the electrode that is covered with cells. When cells become confluent, the resistance reaches the maximum. And conversely, when cells start dying they start de-attaching from the electrode surface which leads to a decrease in the measured impedance $(79,127)$.

Parameters such as resistance of the culture medium as well as the capacitance and resistance of the electrode/electrolyte interface, contribute to the impedance measured by ECIS technique (128). In ECIS measurements, quality of the cell barrier can be demonstrated by resistance of the cells towards the current, while capacitance is a measure of the area of the electrode that is covered by cells (129).

Two electrode configuration is typically used for impedance measurements in ECIS method and measured impedance is highly dependent on the area of the sensing electrode that is covered by cells and also the adherence of the cells that are grown on the electrode (39). 


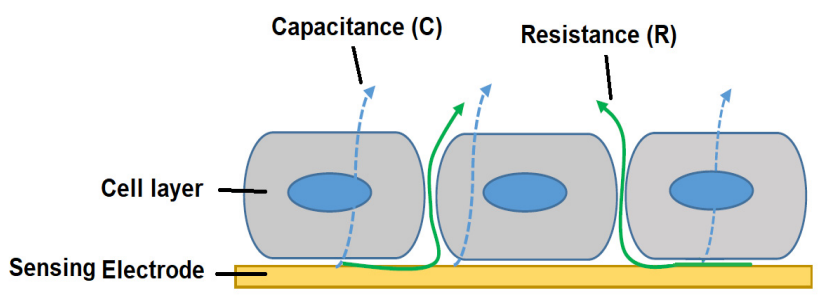

Figure 8. A schematic drawing of an Electric Cell Substrate Impedance Sensing system (ECIS): The insulating membranes of the cells attached to the sensing electrode, cause capacitance (C) by constraining the current and force the current to flow beneath and between the cells which causes resistance (R), therefore in $\mathrm{ECIS}$ both the capacitance and resistance contribute to the measured impedance

\section{Application}

In ECIS the measurement can be performed in two ways: 1) Applying a current at a chosen frequency and measuring the impedance of the cell-covered electrode. This way the magnitude and phase of the voltage as a function of time would be monitored. From the results information regarding cells morphological changes and metabolic activities can be extracted $(126,130)$.

2) Measuring the impedance of the electrode covered with cells at different frequencies. This way information regarding the cell layer covering the electrode surface, including the resistance of the cell barriers and capacitance of the cell membranes can be obtained $(126,131,132)$.

ECIS can provide information regarding the dynamic characteristics of the cells cultured on the electrode surface. Cell adhesion, spreading, density and barrier function, as well as cell micromotion and motility can be studied by this method $(129,133)$.

ECIS has been applied to monitor human bone marrowderived mesenchymal stem cells (hMSCs) undergoing osteogenic differentiation. It has also been used to monitor human adipose-derived stem cells (hASCs) during osteogenic and adipogenic differentiation based on the distinct impedance properties of hMSCs and hASCs (30, 134).

Nordberg et al., reported that the impedance measurements performed by ECIS can be used to quantify donor-related differences during proliferation and osteogenic differentiation in hASC populations (135).

\section{Strength and weaknesses}

ECIS offers a non-invasive, label-free and continuous impedance measurements for monitoring cells characteristics with a high temporal resolution. Although the impedance measurements can be influenced by small changes in temperature, $\mathrm{pH}$ or the medium. In addition, by using mathematical models, changes in the resistance and capacitance can be used to interpret cellular behavior and morphology $(129,136)$. Nevertheless, it should be noted that these mathematical models are only valid when the cells are in their confluent states, therefore one should make sure of the maturity of the cells before modelling them. On the other hand, ECIS cannot be used for measurements on single cells as its measurements are the average of signals from all the cells cultured on the electrode surface. In addition, optimization of parameters such as seeding and coating density of cells prior to ECIS measurements is needed to provide optimal results (129, 137).

One of the drawbacks of ECIS method is that it cannot be used for monitoring 3D cell cultures where cells are encapsulated inside a 3D matrix and therefore cannot attach to the electrode surface. While the major limitation of this method is that direct information on molecular level cannot be provided by $\operatorname{ECIS}(79,127,138)$.

\section{TEER (Trans Endothelial/Epithelial Electrical Resistance) Description}

Trans Endothelial/Epithelial Electrical Resistance or TEER is a non-invasive method which measures the electrical resistance across the tissue and this way quantifies the integrity of the barrier tissue (Endothelial or epithelial monolayers). In TEER method, electrodes are placed on both sides of a cell layer which is grown on a semipermeable membrane (Figure 9).

In Resistance-based TEER measurements, an alternating current signal would be applied and both the current and voltage would be measured across the cell layer. This way the electrical resistance of the cell layer in Ohms would be measured which provides information regarding barrier integrity; while in Impedance-based TEER, impedance measurements are performed across a frequency range (139, 140).

In TEER measurements, many factors contribute to the measured electric resistance including: resistance of the cell layer, cell culture medium, the semi-permeable membrane where the cells are cultured and the electrode-medium interface (141).

In TEER, two electrode configuration can be used to provide accurate TEER measurements, while four electrode configuration can provide even more reliable and robust measurements (140).

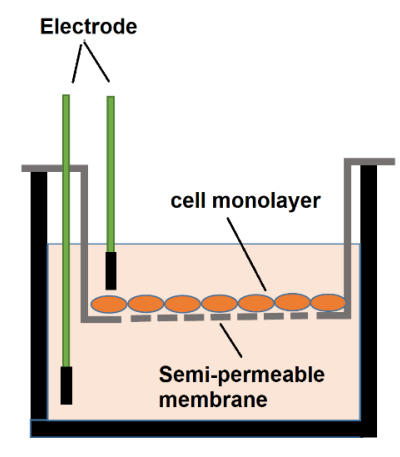

Figure 9. Schematic of Trans Endothelial Electrical Resistance (TEER) measurement system with chopstick electrodes. 


\section{Application}

TEER offers a sensitive and reliable method for monitoring the integrity and permeability of the barrier of the cell monolayer (66). Due to its reliability and noninvasiveness, TEER is considered an important method to be used in body-on-chip microfluidic devices. Commercial TEER measurement systems with customized microfluidic implementations for various cell types have been reported such as blood-brain barrier (BBB), gastrointestinal (GI) tract, and pulmonary models $(139,142)$.

\section{Strength and weaknesses}

TEER measurements provide non-invasive and on-line monitoring of the whole process of cell growth and differentiation as well as their barrier integrity. Although, many factors such as temperature, formulation of the culture medium and also the passage number of cells can influence the measurement. In addition, in order to gain reliable and accurate measurements, all the factors contributing to the measurements including cell monolayer, culture medium, the semi-permeable membrane and electrode-medium interface should be under control. Variation in electrode placement and temperature between the blank and tissue-containing systems in lab-on-chip systems, can also cause errors in the measurements performed by TEER method (140).

\section{EIT (Electrical Impedance Tomography) or ECT (Electrical Capacitance Tomography) \\ Description}

Electrical Impedance Tomography (EIT) is a noninvasive imaging method, in which the conductivity distribution in a tissue is mapped based on electrical measurements from the subject (143).

EIT systems are either Single-frequency where a constant current at a particular frequency is applied and the resulting potential is measured, or Multi-frequency EIT systems where measurements are performed over a frequency range $(143,144)$. Typically in EIT methods, an alternating current with a magnitude of a few $\mathrm{mA}$ is applied to one pair of electrode and the resulting voltages between other electrodes are picked up. Current is then applied to all the other electrode pairs and the voltages are recorded (145). Optimized algorithms are then implemented in order to reconstruct an impedance image based on the electrical measurements (146).

Four electrode configuration is considered an effective way to minimize electrode/electrolyte interface errors in measurements (147). Therefore, by successive measurements based on four electrode configuration, it would be possible to collect electrical data from several electrode pairs and consequently map the impedance of the subject under measurement (46).

EIT measurements can be performed by applying different data collection methods $(101,148)$ (Figure 10) by which the current is injected and the voltages are detected: 1. Adjacent Drive or Neighboring method (149), 2. Opposite method, 3. Cross method (150), 4.Trigonometric or Adaptive method (151).
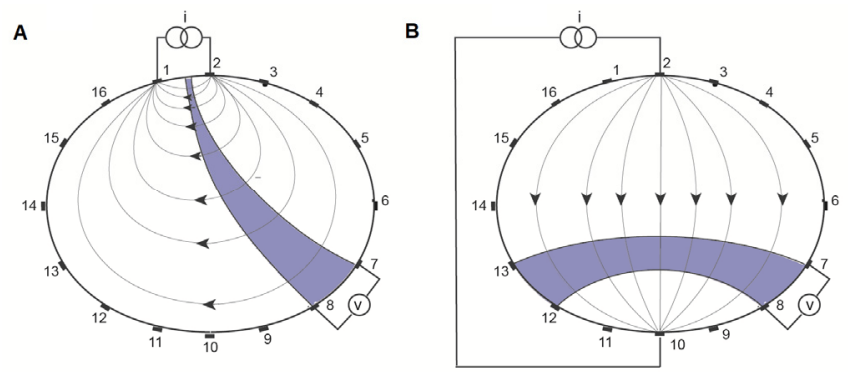

Figure 10. Impedance data collection methods in Electrical Impedance Tomography by applying 16 equally spaced electrodes: A) Adjacent Drive or Neighboring method, B) Opposite method.

\section{Application}

First in 1978, EIT was developed as an alternative and costeffective imaging method for clinical applications such as thorax imaging (152).

Application of EIT at the cellular level started by development of microtechnologies, where EIT measurements were performed by placing microelectrodes inside the cell culture environment. Electrical current with a low magnitude was is then applied and the electrical data were collected and using reconstruction algorithms, the internal conductivity of the cell culture was mapped (153, 154, 155).

EIT is a multi-dimensional (space, time and frequency) direct imaging method, which can provide non-invasive and label-free monitoring of cell growth, proliferation, differentiation, migration and death in cell cultures (156).

Cell culture imaging by EIT has been studied by several research groups: Linderholm et al., presented a novel, lowcost, and fast EIT system for two dimensional imaging of cell cultures. Using a four-electrode configuration set up with 16 planar microelectrodes integrated into the cell culture chamber, 2D impedance images were obtained. This novel imaging method, made it possible to study the shape and position of human hair, and its vertical cross sections. In addition, human epithelial stem cells grown directly on the device surface were monitored by this method (91, 153).

Sun et al., reported a miniaturized EIT system for mapping the conductivity distribution within a twodimensional cell culture. For this purpose, a chip containing a circular 16-electrode array was used to measure spatial voltage across a multi-nuclear single cellular organism. The electrical data was then collected using a four electrode configuration set up and the conductivity distribution images were reconstructed. This way a non-invasive lab-on- 
chip technology for mapping the impedance of single cells was developed $(94,154)$.

In addition, EIT is also a proper method for imaging 3D cell cultures by monitoring the distribution of cells in to $3 \mathrm{D}$ scaffolds, however only a few applications of EIT in 3D imaging are reported. As an example, 3D imaging of breast cancer cell spheroids was performed by Yang et al. (157); and Wu et al., developed an EIT sensor to monitor cell viability in 3D cell spheroids in a single-well system (53).

\section{Strength and weaknesses}

With single-frequency EIT imaging system, measuring the absolute impedance of the tissue cannot be accurate as the position of the electrode is not certain, while multifrequency EIT imaging system, which employs impedance spectroscopy, has made characterization of biological tissues possible (7).

In comparison to other imaging technologies such as confocal and fluorescence microscopy, EIT has a lower spatial resolution which is due to the problem with reconstruction of image from the measurements $(41,158)$. One important factor that contributes to low spatial resolution, is the low signal to noise ratio of the measurements as the result of low voltage variation at the electrode/tissue interface which is the consequence of low conductivity variation in the tissue in comparison to circuitry noise. System calibration is one way to minimize this circuitry noise. The other solution can be using advanced image reconstruction algorithms which use prior knowledge with regards to structure of the tissue under measurement (159).

Lie et al., developed a micro-EIT system (KHU Mark 1 micro-EIT) by using a unique electrode configuration and data collection method. This method could provide images with higher resolution than the conventional impedance imaging methods due to the projected image reconstruction algorithm used. However, suffered from limitations such as underestimation of the volume and artifacts around the secondary current carrying electrode (160).

Later, Lee et al. introduced a new micro-EIT system (KHU Mark 2 micro-EIT) which could overcome some of the limitations of the previous system (KHU Mark 1 micro-EIT) by applying three current patterns which were linearly independent. This way the images could be reconstructed without any interference caused by the secondary current carrying electrodes and thus the quality of the reconstructed images were improved (156).

Although EIT is a low-cost, easy to operate, non-invasive and label-free imaging method which can be applied overtime, but its performance suffers from limitations such as low signal to noise ratio and spatial resolution specially in monitoring 3D scaffolds due to low conductivity variation produced by sparse cell distribution in the scaffolds (53).

\section{CPM (Complex Permittivity Measurements)}

\section{Description}

Complex Permittivity Measurement or CPM is an effective method for non-invasive monitoring of biomaterials. Permittivity in a biological tissue is related to its structure and compositions, and measurement of permittivity is essential for studying the effects of electromagnetic field on the biological tissue (23). Therefore, studies have been performed to measure permittivity in biological tissues (161-164).

Theoretically, permittivity can be characterized by the reaction of a material to polarization by an external field, for example, electric field (9).

Typically, in order to express the electrical properties of a tissue, relative permittivity $\left(\varepsilon_{r}\right)$ would be used which is the ratio of permittivity of tissue $(\varepsilon)$ and the permittivity of vacuum $\left(\varepsilon_{0}=8.854 \mathrm{pF} / \mathrm{m}\right)$, given as $(9)$;

$$
\varepsilon_{r}=\frac{\varepsilon}{\varepsilon_{0}}
$$

The reaction of materials including biological tissues to external fields such as electric fields depends on the frequency of the field. Due to this frequency dependency, an electric field does not change the polarization of the biological tissue instantly, and the change in polarization occurs with a phase difference which describes the phase lag between the applied electric field and change in polarization (161).

When the material to be measured is a dielectric (a dry insulator capable of storing electrical energy) with losses, the term complex permittivity is used to incorporate both the frequency dependency and the dielectric losses ( 7 , $164)$. Thus, complex permittivity $\left(\varepsilon_{c}\right)$ can be given as;

$$
\varepsilon_{\mathrm{c}}=\varepsilon_{\mathrm{r}}-\mathrm{j} \varepsilon_{\mathrm{r}} \tan \delta
$$

Where $\varepsilon_{r}$ is the real part of complex permittivity, $j=\sqrt{-1}$, and $\tan \delta$ is the loss factor. For purely conductive losses;

$$
\tan \delta=\sigma / \omega \varepsilon_{0} \varepsilon_{\mathrm{r}}
$$

Where $\omega$ is the frequency and $\sigma$ is the medium conductivity (23).

Complex permittivity can be measured by different methods such as transmission, reflection, and resonant measurements (23). In a measurement method based on transmission of for example Radio Frequency (RF); the sample to be measured would be loaded on the transmission line and by transmitting RF through the sample, the scattering parameters would be measured and related to permittivity of the material. In the reflection method, the reflection coefficient at the interface between the electrode and the sample under measurement, would be measured to determine the permittivity of the material (165). 
Another method for characterizing the permittivity of a biological tissue, is measuring the capacitance of the tissue and then calculate permittivity based on the relationship between the tissue morphology and the electromagnetic theory $(166,167)$.

\section{Application}

The Complex Permittivity measurement can be a useful monitoring method in the field of tissue engineering. One of the applications can be real-time monitoring of cellular proliferation, growth, and concentration in microporous polymer scaffolds and evaluation of the porosity and structural defects of these scaffolds, as variations in cell concentration inside scaffolds leads to changes in complex permittivity measurements $(168,169)$. In 2003, Bagnaninchi et al., reported the application of complex permittivity measurements for characterizing Chitosan microporous scaffolds at radio frequencies and real-time monitoring of cell growth and concentration in these scaffolds (168).

In 2004, Bagnaninchi et al. proposed the application of CPM for monitoring morphological behavior of osteoblast and macrophages including their attachment, proliferation and differentiation inside microporous scaffolds as well as the structural defects of the scaffolds (169).

\section{Strength and weaknesses}

One major problem with both transmission and reflection methods used for CPM measurements is the multiple reflections happening between the source and the sample which decreased the accuracy of measurements. However, employing a four electrode configuration instead of the two electrode configuration has helped to solve some of these problems $(164,165,170)$.

Permittivity being one of the frequency dependent deielectric properties of the tissue, demonstrated nonlinear characteristics in frequency domain. Therefore, the models used for calculation of the complex permittivity of the biological tissues can face some limitations. Hence, establishing a model proper for the dielectric properties of different constituents in the frequency domain is needed (23).

\section{Conclusions}

The translation of tissue engineered products into clinical routine is often limited by the lack of suitable non-invasive imaging methods to visualize parameters and behavior of the constructs (171). At the moment there are very few non-invasive methods in general use for evaluating the characteristics or viability of tissue engineered constructs. Current analysis methods and protocols employed in cell and tissue engineering are mainly histological techniques that require labeling and involve destructive tests to characterize the cell cultures and tissue engineered constructs (172).
The investigation of the electrical properties of biological materials and their applications has a long history where measuring the dielectric properties of the cells could offer an applicable method for evaluating cell characteristics non-invasively. Tissue engineering, in contrast, is a relatively more recent field of investigation, and the exploration of the use of electric fields for characterizing or actively monitoring tissue engineered constructs offers a great potential (26).

Therefore, impedance measurements could offer a noninvasive and reliable method with high temporal resolution for real-time monitoring of tissue engineered constructs during the production phase, providing the possibility of monitoring cell viability, growing and differentiation. Nevertheless, the measurement system has to be enhanced and different frequencies should be utilized. In this article, applications of bioimpedance measurement techniques in the field of tissue engineering from various reference points were reviewed.

From the electrode point of view, different electrode configurations and their applications in different bioimpedance measurement methods and cell culture types were discussed. Four electrode configuration seems to be able to provide results with higher relative sensitivity to cell density and morphological information in comparison to two electrode measurements which can be inaccurate for multiple layer growths. Therefore the combined use of the two, three and four electrode measurements can provide information with high sensitivity with regards to structural, morphological, spatial distribution and differentiation state of the cells in a 3D cell culture.

From the tissue engineered cell culture point of view, the 3D and lab-on-chip cultures seems to be the closest in mimicking the in-vivo biological systems in comparison to $2 \mathrm{D}$ cell cultures. Of course the complexities of organ functions and other requirements for their simulation on a chip will not allow researchers to replace human testing so easily and lab on chip systems need to be integrated with diverse technologies to enhance their capabilities (173).

When it comes to the proper bioimpedance measurement technique, it should be chosen based on the application and the type of the cell culture which is to be monitored. Consequently the proper electrode configuration is of a high importance. Many of the current systems are not really portable, so developing microsystems with reduced size, both for the cell culture environment and the electrodes and the bioimpedance measurement system could be a subject for the future studies.

Conflict of interest

Authors declare no conflict of interest. 


\section{References}

1. Langer R, Vacanti JP. Advances in tissue engineering. J Pediatr Surg. 2016;51(1):8-12. https://doi.org/10.1016/j.jpedsurg.2015.10.022

2. Dzobo K. Advances in Regenerative Medicine and Tissue Engineering: Innovation and Transformation of Medicine: A Review Article. Stem Cells International. 2018. https://doi.org/10.1155/2018/2495848

3. Shafiee A, Atala A. Tissue Engineering: Toward a New Era of Medicine. Annu Rev Med. 2017;68:29-40. https://doi.org/10.1146/annurev-med-102715-092331

4. Tabata Y. Biomaterial technology for tissue engineering applications. J R Soc Interface. 2009;6(S311). https://doi.org/10.1098/rsif.2008.0448.focus

5. Appel AA, Anastasio MA, Larson JC, Brey EM. Imaging challenges in biomaterials and tissue engineering. Biomaterials. 2013;34(28):6615-30. https://doi.org/10.1016/j.biomaterials.2013.05.033

6. Nam SY, Suggs LJ, Emelianov SY. Imaging strategies for tissue engineerig applications. Tissue Engineering. 2015;21(1).

7. Grimnes $S$, Martinsen $\varnothing \mathrm{G}$. Bioimpedance \& Bioelectricity Basics. 3rd ed: Elsevier Science; 2014.

8. Pethig R, Kell DB. The passive electrical properties of biological systems: Their significance in physiology, biophysics and biotechnology. Phys Med Biol. 1987;32(933). https://doi.org/10.1088/0031-9155/32/8/001

9. Miklavcic D, Pavselj N, Hart FX. Electric Properties of Tissues. Wiley Encyclopedia of Biomedical Engineering. 2006.

10. Schwan HP. Electrical properties of tissue and cell suspensions: Mechanisms and models. Proc IEEE Adv Biol Med Soc. 2002;1:A70-A1.

11. Kyle UG, Bosaeus I, De Lorenzo AD. Bioelectrical impedance analysis part I: review of principles and methods. Clinical Nutrition. 2004;23:1226-43. https://doi.org/10.1016/j.clnu.2004.06.004

12. Alberts $B$, Johnson A, Lewis J. Transport into the cell from the plasma membrane: Endocytosis. Molecular Biology of the Cell. 4th ed: Garland Science; 2002.

13. Asami K. Characterization of heterogeneous systems by dielectric spectroscopy. Prog Polym Sci. 2002;27:1617-59. https://doi.org/10.1016/S0079-6700(02)00015-1

14. Heileman K, Daoud J, Tabrizian M. Dielectric spectroscopy as a viable biosensing tool for cell and tissue characterization and analysis. Biosens Bioelectron. 2013;49:348-59. https://doi.org/10.1016/j.bios.2013.04.017

15. Riu PJ. Comments on "Bioelectrical parameters of the whole human body obtained through bioelectrical impedance analysis". Bioelectromagnetics. 2004;25:69-71. https://doi.org/10.1002/bem.10190

16. Gabriel C, Gabriel S, Corthout E. The dielectric properties of biological tissues: I. Literature survey. Phys Med Biol. 1996;41:2231-49. https://doi.org/10.1088/0031-9155/41/11/001

17. Martinsen $\varnothing \mathrm{G}$, Grimnes $S$, Schwan HP. Interface phenomena and dielectric properties of biological tissue. Encyclopedia of Surface and Colloid Science. 2002;20:2643-53.
18. Dean DA, Ramanathan $T$, Machado D, Sundararajan R. Electrical Impedance Spectroscopy Study of Biological Tissues. J Electrostat. 2008;66(3-4):165-77. https://doi.org/10.1016/j.elstat.2007.11.005

19. Kwon $\mathrm{H}, \mathrm{McEwan} \mathrm{AL}$, Oh TI, Farooq A, Woo EJ, Seo JK. A local region of interest imaging method for electrical impedance tomography with internal electrodes. Comput Math Methods Med. 2013;9. https://doi.org/10.1155/2013/964918

20. Seo JK, Bera TK, Kwon H, Sadleir RJ. Effective Admittivity of Biological Tissues as a Coefficient of Elliptic PDE. Computational and Mathematical Methods in Medicine. 2013;2. https://doi.org/10.1155/2013/353849

21. Schwan HP. Electrical properties of tissues and cell suspensions Advanced Phys Med Biol. 1957;5:147-209.

22. El Khaled D, Castellano NN, Gazquez JA, Perea-Moreno A-J. Dielectric Spectroscopy in Biomaterials: Agrophysics. A Review. Materials. 2016;9(310). https://doi.org/10.3390/ma9050310

23. Zajicek R, Oppl L, Vrba J. Broadband Measurement of Complex Permittivity Using Reflection Method and Coaxial Probes Radioengineering. 2008;17(1).

24. Vorlicek J, Oppl L, Vrba J, editors. Measurement of Complex Permittivity of Biological Tissues. Progress In Electromagnetics Research Symposium Proceeding; 2010; Cambridge, USA.

25. Foster KR, Schwan HP. Dielectric properties of tissues and biological materials: a critical review. Critical Reviews in Biomedical Engineering. 1989;17(1):25-104.

26. Markx GH. The use of electric fields in tissue engineering. A review. Organogenesis. 2008;4(1):11-7. https://doi.org/10.4161/org.5799

27. Pliquett $U$, Prausnitz MR. Electrical impedance spectroscopy for rapid and non-invasive analysis of skin electroporation. In: Electrically Mediated Delivery of Molecules to Cells, Electrochemotherapy, Electrogenetherapy and Transdermal Delivery by Electroporation Totowa, NJ: Humana Press; 2000. https://doi.org/10.1385/1-59259-080-2:377

28. Ducommun P, Kadouri A, Von Stockar U, Marison I. On-line determination of animal cell concentration in two industrial high-density culture processes by dielectric spectroscopy. Biotechnol Bioeng. 2002;77:316-23. https://doi.org/10.1002/bit.1197

29. Justice C, Brix A, Freimark D, Kraume M, Pfromm P, Eichenmueller B. Process control in cell culture technology using dielectric spectroscopy. . Biotechnol. 2011;29:391-401. https://doi.org/10.1016/j.biotechadv.2011.03.002

30. Hildebrandt $\mathrm{C}$, Büth $\mathrm{H}, \mathrm{Cho} \mathrm{S}$, Thielecke H. Detection of the osteogenic differentiation of mesenchymal stem cells in 2D and 3D cultures by electrochemical impedance spectroscopy. J Biotechnol. 2010;148(1):83-90. https://doi.org/10.1016/j.jbiotec.2010.01.007

31. Wu H, Zhou W, Yang Y, Jia J, Bagnaninchi P. Exploring the Potential of Electrical Impedance Tomography for Tissue Engineering Applications. Materials. 2018;11(6):31. https://doi.org/10.3390/ma11060930

32. Khalil SF, Mohktar MS, Ibrahim F. The Theory and Fundamentals of Bioimpedance Analysis in Clinical Status 
Monitoring and Diagnosis of Diseases. A Review. Sensors. 2014;14.

33. Canali C, Heiskanen A, Martinsen $\varnothing \mathrm{G}$, Mohanty S, Dufva M, Wolff A, Emneus J. Impedance-Based Monitoring for Tissue Engineering Applications. In: Simini F, Pedro BF. editor. II Latin American Conference on Bioimpedance. IFMBE Proceedings. 54. New York: Springer; 2016. p. 36-9. https://doi.org/10.1007/978-981-287-928-8_10

34. Yúfera A, Rueda A. A Method for Bioimpedance Measure With Four- and Two-Electrode Sensor Systems. 30th Annual International IEEE EMBS Conference Vancouver, British Columbia, Canada; 2008. https://doi.org/10.1109/IEMBS.2008.4649662

35. Carvalho TS, Fonseca AL, Coutinho ABB, Jotta B, Pino AV, Souza MN. Comparison of bipolar and tetrapolar techniques in bioimpedance measurement. XXIV Congresso Brasileiro de Engenharia Biomédica - CBEB; 2014.

36. Bragos R, Sarro E, Fontova A, Soley A, Cairo J, Bayes-Genis A, et al. Four versus two-electrode measurement strategies for cell growing and differentiation monitoring using electrical impedance spectroscopy. Annual International Conference of the IEEE Engineering in Medicine \& Biology Society. 2006;1:2106-9. https://doi.org/10.1109/IEMBS.2006.260287

37. Sarro E, Fontova A, Soley A, Cairo J, Bayes-Genis A, Rosell J, et al. Four electrode EIS measurement on interdigitated microelectrodes for adherent cell growing and differentiation monitoring. In: Scharfetter $\mathrm{H}$, Merwa R, editors. 13th International Conference on Electrical Bioimpedance and the 8th Conference on Electrical Impedance Tomography 2007. IFMBE Proceedings. 17. New York: Springer; 2007. p. 77. https://doi.org/10.1007/978-3-540-73841-1_23

38. Kalvøy H, Frich L, Grimnes S, Martinsen $\varnothing$ G. Impedance-based tissue discrimination for needle guidance. Physiological Measurements. 2009;30.

39. Radke SM, Alocilja EC. Design and Fabrication of a Microimpedance Biosensor for Bacterial Detection. IEEE Sensor Journal. 2004;4:434-40. https://doi.org/10.1109/JSEN.2004.830300

40. Giaever I. Use of Electric Fields to Monitor the Dynamical Aspect of Cell Behaviour in Tissue Cultures. IEEE Transaction on Biomedical Engineering. 1986; BME 33:242-7. https://doi.org/10.1109/TBME.1986.325896

41. Linderholm P, Bertsch A, Renaud P. Resistivity probing of multi-layered tissue phantoms using microelectrodes. Physiol Meas. 2004;25:645-58. https://doi.org/10.1088/0967-3334/25/3/005

42. Huang X. Simulation of Microelectrode Impedance Changes Due to Cell Growth. IEEE Sensors Journal. 2004;4:576-83. https://doi.org/10.1109/JSEN.2004.831302

43. Canali C, Mohanty S, Heiskanen A. Impedance Spectroscopic Characterisation of Porosity in 3D Cell Culture Scaffolds with Different Channel Networks. Electroanalysis. 2015;27(1):1939. https://doi.org/10.1002/elan.201400413

44. Ragheb T, Geddes LA. The Polarization Impedance of Common Electrode Metals Operated at Low Current Density Annals of Biomedical Engineering. 1991;19:151-63.
45. Geddes LA, Roeder R. Criteria for the selection of materials for implanted electrodes. Annals of Biomedical Engineering. 2003;31(7):879-90. https://doi.org/10.1114/1.1581292

46. Holder D. Electrical Impedance Tomography: Methods, History and Applications. Bristol: Institute of Physics Publishing; 2005.

47. Kalvøy H, Johnsen GK, Martinsen $\varnothing \mathrm{G}$, Grimnes S. New Method for Separation of Electrode Polarization Impedance from Measured Tissue Impedance. The Open Biomedical Engineering Journal. 2011;5:8-13. https://doi.org/10.2174/1874120701105010008

48. Tibbitt MW, Anseth KS. Hydrogels as extracellular matrix mimics for 3D cell culture. Biotechnol Bioeng. 2009;103(4):655-63. https://doi.org/10.1002/bit.22361

49. Mulhall HJ, Hughes MP, Kazmi B, Lewis MP, Labeed FH. Epithelial cancer cells exhibit different electrical properties when cultured in 2D and 3D environments. Biochim Biophys Acta. 2013;1839(11):5136-41. https://doi.org/10.1016/j.bbagen.2013.07.008

50. Huh D, Torisawa YS, Hamilton GA, Kim HJ, Ingber DE. Microengineered physiological biomimicry: organs-on-chips. Lab Chip. 2012;12(12):2156-64. https://doi.org/10.1039/c2lc40089h

51. Zhang B, Radisic M. Organ-on-a-chip devices advance to market. Lab Chip. 2017;17(14):2395-420. https://doi.org/10.1039/C6LC01554A

52. Kieninger J, Weltin A, Flamm H, Urban A. Microsensor systems for cell metabolism - from 2D culture to organ-onchip. Lab Chip. 2018;18:1274-91. https://doi.org/10.1039/C7LC00942A

53. Wu HC, Yang YJ, Bagnaninchi PO, Jia JB. Electrical impedance tomography for real-time and label-free cellular viability assays of 3D tumour spheroids. Analyst. 2018;143(17):418998. https://doi.org/10.1039/C8AN00729B

54. Lee SM, Han N, Lee R, Choi IH, Park YB, Shin JS, et al. Realtime monitoring of $3 \mathrm{D}$ cell culture using a $3 \mathrm{D}$ capacitance biosensor. Biosensors and Bioelectronics. 2016;77:56-61. https://doi.org/10.1016/j.bios.2015.09.005

55. Knight E, Przyborski S. Advances in $3 \mathrm{D}$ cell culture technologies enabling tissue-like structures to be created in vitro: Reveiw Article. J Anat. 2015;227:746-56. https://doi.org/10.1111/joa.12257

56. Abbott A. Cell culture: Biology's new dimension. Nature. 2003;424:870-2. https://doi.org/10.1038/424870a

57. Engler AJ, Sen S, Sweeney HL, Discher DE. Matrix Elasticity Directs Stem Cell Lineage Specification. J Biomech Eng. 2006;126:677-89. https://doi.org/10.1016/j.cell.2006.06.044

58. Griffith LG, Swartz MA. Capturing complex 3D tissue physiology in vitro. Nat Rev Mol Cell Biol. 2006;7:211-24. https://doi.org/10.1038/nrm1858

59. Antoni D, Burckel H, Josset E, Noel G. Three-Dimensional cell culture: A breakthrough in Vivo. Int J Mol Sci. 2015;16(3):5517-27. https://doi.org/10.3390/ijms16035517

60. Zhang Y. Tissue-specific extracellular matrix coatings for the promotion of cell proliferation and maintenance of cell phenotype. . Biomaterials. 2009;30:4021-8. https://doi.org/10.1016/j.biomaterials.2009.04.005 
61. Halfter W. New concepts in basement membrane biology.

FEBS J. 2015;282:4466-79. https://doi.org/10.1111/febs.13495

62. Lei KF. Review on Impedance Detection of Cellular Responses in Micro/Nano Environment Micromachines. 2014;5:1-12.

63. Smith LE, Smallwood R, Macneil S. A comparison of imaging methodologies for 3D tissue engineering. Microsc Res Tech. 2010;73(12):1123-33. https://doi.org/10.1002/jemt.20859

64. Andersson $\mathrm{H}$, Van den Berg A. Microfabrication and microfluidics for tissue engineering: state of the art and future opportunities. Lab Chip. 2004;4(2). https://doi.org/10.1039/b314469k

65. Erickson D, Li D. Integrated microfluidic devices: A Review. Analytica Chimica Acta 2004;507:11-26. https://doi.org/10.1016/j.aca.2003.09.019

66. Huh D, Kim HJ, Fraser JP. Microfabrication of Human Organson-Chips. Nat Protoc. 2013;8:2135-57. https://doi.org/10.1038/nprot.2013.137

67. Sung JH, Esch MB, Prot JM. Microfabricated Mammalian Organ Systems and Their Integration into Models of Whole Animals and Humans. Lab Chip. 2013;13:1201-12. https://doi.org/10.1039/c3lc41017j

68. Stancescu M, Molnar P, McAleer CW, al. e. A phenotypic in vitro model for the main determinants of human whole heart function. Biomaterials. 2015;60:20-30. https://doi.org/10.1016/j.biomaterials.2015.04.035

69. Oleaga C, Bernabini C, Smith AS, al. e. Mulit-organ toxicity demonstration in a functional human in vitro system composed of four organs. Sci Rep. 2016;6(20030).

70. Sakolish CM. Modeling Barrier Tissues in Vitro: Methods, Achievements and challenges. The Lancet. 2016;5:30-9.

71. Ostrovidov S, Sakai Y, Fujii T. Integration of a pump and an electrical sensor into a membrane-based PDMS microbioreactor for cell culture and drug testing. Biomed Microdevices. 2011;13(5):847-64. https://doi.org/10.1007/s10544-011-9555-1

72. Meyvantsson I, Warrick JW, Hayes S, Skoien A, Beebe DJ. Automated cell culture in high density tubeless microfluidic device arrays Lab on a Chip. 2008(5).

73. Zervantonakis IK. Microfluidic devices for studying heterotypic cell-cell interactions and tissue specimen cultures under controlled microenvironments. Biomicrofluidics. 2011;5. https://doi.org/10.1063/1.3553237

74. Li X, Valadez A, Zuo P, Nie Z. Microfluidic 3D cell culture: Potential application for tissue-based bioassays. Bioanalysis. 2012;4:1509-25. https://doi.org/10.4155/bio.12.133

75. Asphahani F, Zhang M. Cellular impedance biosensors for drug screening and toxin detection. Analyst. 2007;132(9):83541. https://doi.org/10.1039/b704513a

76. Kilic T, Navaee F, Stradolini F, Renaud P, Carrara S. Organs-onchip monitoring: sensors and other strategies. Review Article. Microphysiological Systems. 2018;2(5).

77. Huang HH, Pan SJ, Lu FH. Surface electrochemical impedance in situ monitoring of cell-cultured titanium with a nanonetwork surface layer. Scripta Materialia. 2005;53(9):103742. https://doi.org/10.1016/j.scriptamat.2005.07.006
78. Kim HJ, Huh D, Hamilton G, Ingber DE. Human gut-on-a-chip inhabited by microbial flora that experiences intestinal peristalsis-like motions and flow. Lab Chip. 2012;12(12):216574. https://doi.org/10.1039/c2lc40074j

79. Daza P, Olmo A, Canete D, Yufera A. Monitoring living cell assays with bio-impedance sensors. Sensors and Actuators B: Chemical. 2013;176:605-10.

https://doi.org/10.1016/j.snb.2012.09.083

80. Serrano JA, Pérez $P$, Maldonado A, Martín M, Olmo A, Daza P, et al., editors. Practical Characterization of cell-electrode electrical models in bioimpedance assays In Proceedings of the 11th International Joint Conference on Biomedical Engineering Systems and Technologies (BIOSTEC); 2018. https://doi.org/10.5220/0006712601000108

81. Ducommun P, Ruffieux PA, Kadouri A. Process Development in a Packed Bed Bioreactor. Animal Cell Technology: From Target to Market2002.

82. Gloeckner $\mathrm{H}$, Jonuleit $\mathrm{T}$, Lemke HD. Monitoring of cell viability and cell growth in a hollow-fiber bioreactor by use of the dye Alamar Blue. Journal of Immunological Methods. 2001;252:131-8. https://doi.org/10.1016/S0022-1759(01)00347-7

83. K'Owino IO, Sadik OA. Impedance spectroscopy: A powerful tool for rapid biomolecular screening and cell culture monitoring. Electroanalysis. 2005;17(23):2101-13. https://doi.org/10.1002/elan.200503371

84. Bürgel SC, Diener L, Frey O, Kim JY, Hierlemann A. Automated, Multiplexed Electrical Impedance Spectroscopy Platform for Continuous Monitoring of Microtissue Spheroids. Anal Chem. 2016;88(22). https://doi.org/10.1021/acs.analchem.6b01410

85. Schmid YRF, Burgel SC. Electrical Impedance Spectroscopy for Microtissue Spheroid Analysis in Hanging-Drop Networks. ACS Sens. 2016;1(8).

86. Krommenhoek EE. Monitoring of yeast cell concentration using a micromachnined impedance sensor. Sensors and actuators B: Chemical. 2006;115(1). https://doi.org/10.1016/j.snb.2005.09.028

87. Sharma R. On-chip microelectrode impedance analysis of mammalian cell viability during biomanufacturing. Biomicrofluidics. 2014;8(5). https://doi.org/10.1063/1.4895564

88. Stolwijk J, Hartmann C, Balani P, Albermann S, Keese C. Impedance analysis of adherent cells after in situ electroporation: non-invasive monitoring during intracellular manipulations. BiosensBioelectron. 2011 26:4720-7. https://doi.org/10.1016/j.bios.2011.05.033

89. Senez V, Lennon E, Ostrovidov S, Yamamoto T, Fujita H, Sakai $Y$, et al. Integrated 3-D Silicon Electrodes for Electrochemical Sensing in Microfluidic Environments: Application to SingleCell Characterization IEEE Sens J. 2008:548-57. https://doi.org/10.1109/JSEN.2008.918948

90. Rissanen AK, editor Monitoring Capillary Endothelial Cell Culture and Capillary Formation in a Microdevice by Impedance Spectroscopy Measurements. . Proceedings of the 3rd Annual International IEEE EMBS Special Topic Conference on Microtechnologies in Medicine and Biology; 2005. https://doi.org/10.1109/MMB.2005.1548426 
91. Linderholm P, Braschler T, Vannod J, Barrandon Y, Brouard M, Renaud P. Two-dimensional impedance imaging of cell migration and epithelial stratification. Lab Chip. 2006;6:115562. https://doi.org/10.1039/b603856e

92. Gawad S. Dielectric spectroscopy in a micromachined flow cytometer: theoretical and practical considerations. Lab on a Chip. 2004(3).

93. Jang L-S, Wang M-H. Microfluidic device for cell capture and impedance measurement. Biomedical Microdevices. 2007;9:737-43. https://doi.org/10.1007/s10544-007-9084-0

94. Sun T, Tsuda S, Zauner KP, Morgan H. On-chip electrical impedance tomography for imaging biological cells. Biosens Bioelectron. 2010;25:1109-15. https://doi.org/10.1016/j.bios.2009.09.036

95. Malleo D. Continuous differential impedance spectroscopy of single cells. Microfluidics and Nanofluidics. 2010;9(2-3). https://doi.org/10.1007/s10404-009-0534-2

96. Schade-Kampmann G, Huwiler A, Hebeisen M, Hessler T, Di Berardino M. On-chip non-invasive and label-free cell discrimination by impedance spectroscopy. Cell Proliferation in basic and clinical sciences. 2008;41(5).

97. Holmes D. Leukocyte analysis and differentiation using high speed microfluidic single cell impedance cytometry Lab on a Chip. 2009(20).

98. Keese CR, Wegener J, Walker SR, Giaever I. Electrical woundhealing assay for cells in vitro. PNAS 2004;101(6). https://doi.org/10.1073/pnas.0307588100

99. Wang P, Liu Q. Cell-Based Biosensors: Principles and Applications. 2010.

100. Fricke $\mathrm{H}$, Morse $\mathrm{S}$. The electrical resistance and capacity of blood for frequencies between $800 \mathrm{~Hz}$ and $4.5 \mathrm{MHz}$. J Gen Physiol. 1925;9:153-67. https://doi.org/10.1085/jgp.9.2.153

101. Wang M. Electrode models in electrical impedance tomography. J Zhejiang Univ Sci A. 2005;6:1386-93. https://doi.org/10.1631/jzus.2005.A1386

102. Daniels JS, Pourmand N. Label-Free Impedance Biosensors: Opportunities and Challenges: A Review. Electroanalysis. 2007;19(12):1239-57. https://doi.org/10.1002/elan.200603855

103. Bera TK, Nagaraju J. Electrical Impedance Spectroscopic Studies on Broiler Chicken Tissue Suitable for the Development of Practical Phantoms in Multifrequency EIT Journal of Electrical Bioimpedance. 2011;2:48-63. https://doi.org/10.5617/jeb.174

104. Bera TK. Bioelectrical Impedance Methods for Noninvasive Health Monitoring: A Review. J Med Eng. 2014;2014.

105. Bouchaala D, Kanoun O, Derbel N. High accurate and wideband current excitation for bioimpedance health monitoring systems. Measurement. 2015;79:339-48. https://doi.org/10.1016/j.measurement.2015.07.054

106. Kerner TE. Electrical impedance spectroscopy of the breast: clinical imaging results in 26 subjects. IEEE Trans Med Imaging. 2002;21(6):638-45. https://doi.org/10.1109/TMI.2002.800606

107. Aberg P. Skin cancer identification using multifrequency electrical impedance-a potential screening tool. IEEE Trans
Biomed Eng. 2004;51:2097-102.

https://doi.org/10.1109/TBME.2004.836523

108. Osterman KS. Non-invasive assessment of radiation injury with electrical impedance spectroscopy. Phys Med Biol. 2004;49:665-83. https://doi.org/10.1088/0031-9155/49/5/002

109. Brown BH. Detection of cervical intraepithelial neoplasia using impedance spectroscopy: a prospective study. BJOG: An Int J Obstet Gynaecol. 2005;112:802-6. https://doi.org/10.1111/j.1471-0528.2004.00530.x

110. Süselbeck T, Thielecke H, Köchlin J, Cho S, Weinschenk I, Metz $\mathrm{J}$, et al. Intravascular electric impedance spectroscopy of atherosclerotic lesions using a new impedance catheter system. Basic Res Cardiol. 2005;100:446-52. https://doi.org/10.1007/s00395-005-0527-6

111. Soley A. On-line monitoring of yeast cell growth by impedance spectroscopy. J Biotechnol 2005;118:398-405. https://doi.org/10.1016/j.jbiotec.2005.05.022

112. Strand-Amundsen R, Tronstad C, Kalvøy H, Gundersen $Y$, Krohn CD, Aasen AO, Holhjem L, Reims HM, Martinsen $\varnothing \mathrm{G}$, $H \varnothing$ getveit JO, Ruud TE, Tønnessen TI. In vivo characterization of ischemic small intestine using bioimpedance measurements. Physiological Measurement. 2016;37(2):25775. https://doi.org/10.1088/0967-3334/37/2/257

113. Strand-Amundsen R, Høgetveit JO, Tronstad C. Small intestinal ischemia and reperfusion - Bioimpedance measurements. Physiological Measurement. 2018;39(2). https://doi.org/10.1088/1361-6579/aaa576

114. Hildebrandt C, Thielecke H. Non-invasive Characterization of the Osteogenic Differentiation of hMSCs in 3D by Impedance Spectroscopy. In: Dossel O, Schlegel WC, editors. World Congress on Medical Physics and Biomedical Engineering, Vol 25, Pt 10: Biomaterials, Cellular and Tissue Engineering, Artificial Organs. IFMBE Proceedings. 25. New York: Springer; 2009. p. 81-84. https://doi.org/10.1007/978-3-642-03900-3_24

115. Yuste $Y$, Serrano, J., Olmo, A., Maldonado-Jacobi, A., Pérez, P., Huertas, G., Pereira, S., Portilla, F. and Yúfera, A., editor Monitoring Muscle Stem Cell Cultures with Impedance Spectroscopy. In Proceedings of the 11th International Joint Conference on Biomedical Engineering Systems and Technologies (BIOSTEC 2018); 2018. https://doi.org/10.5220/0006712300960099

116. Martínez-Teruel J, García-Sánchez T, Fontova A, Bragós R. Electrical Impedance Spectroscopy cell monitoring in a miniaturized bioreactor 19th IMEKO TC 4 Symposium and 17th IWADC Workshop Advances in Instrumentation and Sensors Interoperability Barcelona, Spain 2013.

117. Xu Y, Xie X. Review of impedance measurements of whole cells. Biosensors \& Bioelectronics. 2015;77(77).

118. Pérez $P$, Maldonado-Jacobi A, López A, Martínez C, Olmo A, Huertas G, et al. "Remote Sensing of Cell Culture Assays. Cell Culture: InTech Europe; 2017.

119. DePaola N, Phelps JE, Florez L, Keese CR, Minnear FL, Giaever I, et al. Electrical impedance of cultured endothelium under fluid flow. Annals of Biomedical Engineering. 2001;29(8):64856. https://doi.org/10.1114/1.1385811 
120. Wang H, Sobahi N, Han A. Impedance spectroscopy-based cell/particle position detection in microfluidic systems Lab on a Chip. 2017;7. https://doi.org/10.1039/C6LC01223J

121. Kozhevnikov E, Hou XL, Qiao SP, Zhao YF, Li CF, Tian WM. Electrical impedance spectroscopy - a potential method for the study and monitoring of a bone critical-size defect healing process treated with bone tissue engineering and regenerative medicine approaches. Journal of Materials Chemistry B. 2016;4(16):2757-67. https://doi.org/10.1039/C5TB02707A

122. Kiviharju K, Salonen K, Moilanen U, Meskanen E, Leisola M, Eerikäinen T. On-line biomass measurements in bioreactor cultivations: comparison study of two on-line probes. . J Ind Microbiol Biotechnol. 2007;34(8):561-6. https://doi.org/10.1007/s10295-007-0233-5

123. Liu JJ, Li H, Zhang F, Li X, Wang L, Chen Y. Online impedance monitoring of yeast cell culture behaviors. Microelectronic Engineering. 2011;88(8):1711-3.

https://doi.org/10.1016/j.mee.2010.12.056

124. Holhjem L, Strand-Amundsen R, Aasmundtveit KE, Tønnessen TI. Development of a conductometric biocompatible sensor for detecting ischemia. Microelectronics Packaging Conference (EMPC); European2013.

125. El Khaled D, Novas N, Gazquez JA, Manzano-Agugliaro F. Dielectric and Bioimpedance Research Studies: A Scientometric Approach Using the Scopus Database. A Review. MDPI Publications. 2018;6(6).

126. Giaever I, Keese CR. Micromotion of mammalian cells measured electrically. Proc Nail Acad Sci USA Cell Biology. 1991;88:7896-900. https://doi.org/10.1073/pnas.88.17.7896

127. Jeong SH, Lee DW, Kim S, Kim J, Ku B. A study of electrochemical biosensor for analysis of three-dimensional (3D) cell culture. Biosens Bioelectron. 2012;35:128-33. https://doi.org/10.1016/j.bios.2012.02.039

128. Wegener J, Sieber M, Galla HJ. Impedance analysis of epithelial and endothelial cell monolayers cultured on gold surfaces. J Biochem Biophys Methods 1996;32(3):151-70. https://doi.org/10.1016/0165-022X(96)00005-X

129. Szulcek R, Bogaard HJ, Van Nieuw Amerongen GP. Electric Cell-substrate Impedance Sensing for the Quantification of Endothelial Proliferation, Barrier Function, and Motility. J Vis Exp 2014;85(51300). https://doi.org/10.3791/51300

130. Lo CM, Keese CR, Giaever I. Monitoring motion of confluent cells in tissue culture. Exp Cell Res 1993;204(1):102-9. https://doi.org/10.1006/excr.1993.1014

131. Giaever I, Keese CR. A morphological biosensor for mammalian cells. Nature. 1993;366:591-2. https://doi.org/10.1038/366591a0

132. Lo CM, Keese CR, Giaever I. Impedance analysis of MDCK cells measured by electric cell-substrate impedance sensing. Biophys J. 1995;69(6):2800-7. https://doi.org/10.1016/S0006-3495(95)80153-0

133. Rahim S, Uren A. A Real-time Electrical Impedance BasedTechnique to Measure Invasion of Endothelial Cell Monolayer by Cancer Cells. Journal of Visualized Experiments. 2011;50.
134. Bagnaninchi PO, Holmes C, Drummond N, Daoud J, Tabrizian M. Measurements of adipose derived stem cell vitality with optical coherence phase microscopy. Dynamics and Fluctuations in Biomedical Photonics Viii. Proceedings of SPIE. 7898. Bellingham: Spie-Int Soc Optical Engineering; 2011.

135. Nordberg RC, Zhang J, Griffith EH, Frank MW, Starly B, Loboa EG. Electrical Cell-Substrate Impedance Spectroscopy Can Monitor Age-Grouped Human Adipose Stem Cell Variability During Osteogenic Differentiation. Stem Cells Translational Medicine. 2016;07:07.

136. Pänke O, Balkenhohl T, Kafka J, Schäfer D, Lisdat F. Impedance spectroscopy and biosensing. Adv Biochem Eng Biotechnol 2008;109:195-237. https://doi.org/10.1007/10_2007_081

137. Wegener J, Keese CR, Giaever I. Electric cell-substrate impedance sensing (ECIS) as a noninvasive means to monitor the kinetics of cell spreading to artificial surfaces. Exp Cell Res 2000;259(1):158-66. https://doi.org/10.1006/excr.2000.4919

138. Nguyen DT, Kosobrodov R, et al. Electrode-Skin contact impedance: In vivo measurements on an ovine model. Journal of Physics: Conference Series 4342013. https://doi.org/10.1088/1742-6596/434/1/012023

139. Srinivasan B, Kolli AR, Esch MB, Abaci HE, Shuler ML, Hickman JJ. TEER measurement techniques for in vitro barrier model systems. J Lab Autom. 2015;20(2):107-26. https://doi.org/10.1177/2211068214561025

140. Elbrecht DH, Long CJ, Hickman JJ. Transepithelial/endothelial Electrical Resistance (TEER) theory and applications for microfluidic body-on-a-chip devices. J Rare Dis Res Treat. 2016;1(3):46-52. https://doi.org/10.29245/2572-9411/2016/3.1026

141. Benson K, Cramer S, Galla HJ. Impedance-based cell monitoring: barrier properties and beyond. Fluids Barriers CNS. 2013;10(5). https://doi.org/10.1186/2045-8118-10-5

142. Zucco F, Batto AF, Bises G. An Inter-Laboratory Study to Evaluate the Effects of Medium Composition on the Differentiation and Barrier Function of Caco-2 Cell Lines. AtlaAltern Lab Anim. 2005;33:603-18.

143. Bera TK. Applications of Electrical Impedance Tomography (EIT): A Short Review. IOP Conf Ser: Mater Sci Eng. 2018. https://doi.org/10.1088/1757-899X/331/1/012004

144. Bera TK, Nagaraju J. Electrical impedance tomography (EIT): a harmless medical imaging modality, research developments. Computer vision and image processing: methodologies and applications. USA: IGI Global; 2013. p. 224-62.

145. Bayford R, Tizzard A. Bioimpedance imaging: an overview of potential clinical applications. Analyst. 2012;137(20):4635-43. https://doi.org/10.1039/c2an35874c

146. Lionheart WRB, Kaipio J, McLeod CN. Generalized optimal current patterns and electrical safety in EIT. Physiol Meas. 2001;22(1):85-90. https://doi.org/10.1088/0967-3334/22/1/311

147. Wang BS, Weiland JD. Analysis of the Peak Resistance Frequency Method. IEEE Transactions on Biomedical Engineering. 2016;63(10):2086-94. https://doi.org/10.1109/TBME.2015.2510335 
148. Malmivuo J, Plonsey R. Bioelectromagnetism: Principles and Application of Bioelectric and Biomagnetic Fields. 1995 (Oxford University Press, New York). https://doi.org/10.1093/acprof:oso/9780195058239.001.0001

149. Brown B, Seagar A. The Sheffield data collection system. Clin Phys Physiol Meas. 1987;8(91). https://doi.org/10.1088/0143-0815/8/4A/012

150. Hua P, Webster JG, Tompkins WJ, editors. Effect of the measurement method on noise handling and image quality of EIT imaging. In Proc Ninth Int Conf IEEE Eng In Med And Biol Society. 1987; New York.

151. Gisser DG, Isaacson D, Newell JC. Current topics in impedance imaging. Clin Phys Physiol Measurement. 1987;8:39-46. https://doi.org/10.1088/0143-0815/8/4A/005

152. Wang BH, Weiland JD, leee. Resistivity Profiles of Wild-type, rd1, and rd10 Mouse Retina. 2015 37th Annual International Conference of the leee Engineering in Medicine and Biology Society. IEEE Engineering in Medicine and Biology Society Conference Proceedings. New York: leee; 2015. p. 1650-3.

153. Linderholm P, Marescot L, Loke MH, Renaud P. Cell culture imaging using microimpedance tomography. IEEE Trans Biomed Eng. 2008;55:138-46. https://doi.org/10.1109/TBME.2007.910649

154. Sun T, Tsuda S, Green NG. On-chip electrical impedence tomography for monitoring the kinetics in the cell culture. International Conference on Miniaturized Systems for Chemistry and Life Sciences; 2008.

155. Agarwal S, Curtin J, Duffy B, Jaiswal S. Biodegradable magnesium alloys for orthopaedic applications: $A$ review on corrosion, biocompatibility and surface modifications. Materials Science \& Engineering C-Materials for Biological Applications. 2016;68:948-63. https://doi.org/10.1016/j.msec.2016.06.020

156. Lee EJ, Wi H, McEwan AL, Farooq A, Sohal H, Woo EJ, et al. Design of a microscopic electrical impedance tomography system for 3D continuous non-destructive monitoring of tissue culture. Biomedical Engineering Online. 2014;13:142. https://doi.org/10.1186/1475-925X-13-142

157. Yang Y, Jia J, Smith S, Jamil N, Gamal W, Bagnaninchi PO. A miniature electrical impedance tomography sensor and 3-D image reconstruction for cell imaging. IEEE Sens J. 2017;17:514-23. https://doi.org/10.1109/JSEN.2016.2631263

158. Linderholm P, Vannod J, Barrandon Y, Renaud P. Bipolar resistivity profiling of 3D tissue culture. Biosens Bioelectron. 2007;22:789-96. https://doi.org/10.1016/j.bios.2006.02.016

159. McEwan A, Romsauerova A, Yerworth R, Horesh L, Bayford R, Holder D. Design and calibration of a compact multifrequency EIT system for acute stroke imaging. Physiological Measurement. 2006;27(5):S199-S210. https://doi.org/10.1088/0967-3334/27/5/S17

160. Liu Q, Oh TI, Woo EJ. Design of a microscopic electrical impedance tomography system using two current injections. Physiological Measurement. 2011;32(9):1505-16. https://doi.org/10.1088/0967-3334/32/9/011

161. Li G, Pang XF. Effects of electromagnetic field exposure on electromagnetic properties of biological tissues. Progress in
Biochemistry and Biophysics. 2011;38:604-10.

https://doi.org/10.3724/SP.J.1206.2010.00537

162. Farsaci F, Tellone E, Cavallaro M, Russo A, Ficarra S. Low frequency dielectric characteristics of human blood: a nonequilibrium thermodynamic approach. Journal of Molecular Liquids. 2013;188:113-9. https://doi.org/10.1016/j.molliq.2013.09.033

163. Leroy J, Dalmay C, Landoulsi A. Microfluidic biosensors for microwave dielectric spectroscopy. Sensors and Actuators, A: Physical. 2015;229:172-81. https://doi.org/10.1016/j.sna.2015.04.002

164. Gun L, Ning D, Liang Z. Effective Permittivity of Biological Tissue: Comparison of Theoretical Model and Experiment. Mathematical Problems in Engineering. 2017;2017.

165. Ocera A, Dionigi M, Fratticcioli E, Sorrentino R. A novel technique for complex permittivity measurement based on a planar four-port device. IEEE Transactions on Microwave Theory and Techniques. 2006;54(6). https://doi.org/10.1109/TMTT.2006.872914

166. Marzec E, Warchoł W. Dielectric properties of a proteinwater system in selected animal tissues. Bioelectrochemistry. 2005;65(2):89-94. https://doi.org/10.1016/j.bioelechem.2004.10.001

167. Dai T, Adler A. In vivo blood characterization from bioimpedance spectroscopy of blood pooling. IEEE Transactions on Instrumentation and Measurement. 2009;58(11):3831-8. https://doi.org/10.1109/TIM.2009.2020836

168. Bagnaninchi PO, Dikeakos M, Veres T, Tabrizian M. Towards on-line monitoring of cell growth in microporous scaffolds: Utilization and interpretation of complex permittivity measurements. Biotechnology \& Bioengineering. 2003;84(3):343-50. https://doi.org/10.1002/bit.10770

169. Bagnaninchi PO, Dikeakos M, Veres T, Tabrizian M. Complex permittivity measurement as a new noninvasive tool for monitoring in vitro tissue engineering and cell signature through the detection of cell proliferation, differentiation, and pretissue formation. IEEE Transactions on Nanobioscience. 2004;3(4):243-50. https://doi.org/10.1109/TNB.2004.837901

170. Vorlicek J, Vrba J. Coaxial Probe for Measuring Complex Permittivity of Biological Tissues. Radioterapie. 2009:59.

171. Frese J, Hrdlicka L, Mertens ME, Rongen L, Koch S, Schuster P, et al. Non-invasive Imaging of Tissue-Engineered Vascular Endothelium with Iron Oxide Nanoparticles. Biomed Tech. 2012;57. https://doi.org/10.1515/bmt-2012-4472

172. Jaatinen L, Sippola L, Kellomaki M, Miettinen S, Suuronen R, Hyttinen J. Bioimpedance Measurement Setup for the Assessment of Viability and Number of Human Adipose Stem Cells Cultured as Mono layers. In: Dossel O, Schlegel WC, editors. World Congress on Medical Physics and Biomedical Engineering, Vol 25, Pt 10: Biomaterials, Cellular and Tissue Engineering, Artificial Organs. IFMBE Proceedings. 25. New York: Springer; 2009. p. 286-288.

173. Aziz AUR, Geng C, Fu M, Yu X, Qin K, Liu B. The Role of Microfluidics for Organ on Chip Simulations: Review. Bioengineering. 2017;4(39). 